\title{
DRY MATTER AND PROTEIN YIELD OF ALFALFA, COCKSFOOT, MEADOW FESCUE, PERENNIAL RYEGRASS AND THEIR MIXTURES UNDER THE INFLUENCE OF VARIOUS DOSES OF NITROGEN FERTILIZER
}

\author{
Z. Tomić ${ }^{1}$, Z. Bijelić ${ }^{1}$, M. Žujović ${ }^{1}$, A. Simić ${ }^{2}$, M. Kresović ${ }^{2}$, V. Mandić ${ }^{1}$, \\ G. Marinkov ${ }^{1}$ \\ ${ }^{1}$ Institute for Animal Husbandry, Autoput 16, 11080, Belgrade-Zemun, Republic of Serbia \\ ${ }^{2}$ Faculty of Agriculture, Nemanjina 6, 11080, Belgrade-Zemun, Republic of Serbia \\ Corresponding author: zotom@mail.com \\ Original scientific paper
}

Abstract: Grass-leguminous mixtures and pure crops are important for ensuring of sufficient quantities of high quality roughage, especially in conditions of low land livestock production, in conditions of farm housing system as well as in the system of free grazing of animals. Studies were carried out on pure crops of three grass species and their mixtures with different component ratios. Fertilization using different doses of nitrogen led to considerable increase of yield of pure crops and their mixtures. The highest yields were recorded in treatment with $100 \mathrm{kgN} \mathrm{ha}{ }^{-}$ 1 , and the lowest yield in treatment without fertilization. Fertilization led to decrease of share of alfalfa, meadow fescue and perennial ryegrass in dry matter, and increased the content of cocksfoot. The highest protein yield of pure crops was recorded for perennial ryegrass - 495.5, and in mixtures, the highest protein yield was recorded for four component mixture of alfalfa, cocksfoot, meadow fescue and perennial ryegrass of $568.0 \mathrm{~kg} \mathrm{ha}^{-1}$. Fertilization with $\mathrm{N}$ increased protein yield considerably in pure crops as well as in their mixtures.

Key words: grass-legume mixture, DM yield, protein production

\section{Introduction}

Grass-leguminous mixtures, as well as pure crops, are important for production of roughage of good quality, especially in low land livestock production, in conditions of farm housing system as well as in the system of free grazing of animals. Alfalfa is forage leguminous plant most often used in animal nutrition (Radovic et al., 2009). It is often cultivated in mixture with one or several grass species: Timothy grass, meadow fescue or cocksfoot (Jönsson, 1982). 
Growing of alfalfa and other leguminous plants in mixtures with grasses has many advantages, such as possibility for their use by grazing, i.e. use of fresh plants, which reduces the risk of incidence of bloat (Ocokoljić et al., 1984), reduces the weed infestation of crops, ensures better conservation of water and mineral matters in the soil (Lazaridou et al., 2006) and enables more successful ensiling because of higher sugar content (Đorđević and Dinić, 2003, 2005). By comparing the pure grass crop with mixture of grasses and leguminous plants, mixtures have the advantage due to greater and more uniform yield of mixtures over grasses (Spandl and Hesterman, 1997), better forage quality, (Gil and Fick, 2001), better utilization of nutritious substances from the soil and more economically efficient production due to reduced use of nitrogen fertilizers (Tekeli and Ates, 2005). However, regardless of the nitrogen fixation abilities of leguminous plants, nitrogen fertilizers applied in certain quantities, in the grass-leguminous crop increases the yield of dry matter and protein content and yield. Komarek et al. (2007) in their research of the effect of complex mineral fertilizers with and without nitrogen on yield of grasslands concluded that by adding $90 \mathrm{kgN} \mathrm{ha}^{-1}$ the yield of dry matter increased by $1.89 \mathrm{t} \mathrm{ha}^{-1}$, and adding of $180 \mathrm{kgN} \mathrm{ha}^{-1}$ by $3.03 \mathrm{t} \mathrm{ha}^{-1}$. In studies by Ocokoljić et al. (1974) fertilization influenced significantly the increase of crude protein content in mixture of alfalfa and cocksfoot by $17,6 \%$.

Objective of this study was to investigate the effect of different $\mathrm{N}$ quantities from mineral fertilizers on production and quality characteristics of forage crops as mono-culture and in mixtures.

\section{Materials and Methods}

Trial was set at the trial field of the Institute for Animal Husbandry, according to random block system in four repetitions. The effect of three nitrogen doses $\left(0,50\right.$ and $\left.100 \mathrm{~kg} \mathrm{ha}^{-1}\right)$ on yield of dry matter and protein was studied in pure crops (alfalfa, cocksfoot, meadow fescue and perennial ryegrass) and grassleguminous mixtures (Alfalfa 50\%: Cocksfoot 50\%, Alfalfa 50\%: Cocksfoot 25\%: Meadow fescue 25\%, Alfalfa 25\%: Cocksfoot 50\%: Meadow fescue $25 \%$, Alfalfa 40\%: Cocksfoot 20\%: Meadow fescue $20 \%$ : Perennial ryegrass $20 \%$ ). For sowing the alfalfa cultivar K-28 was used in the amount of $20 \mathrm{~kg} \mathrm{ha}^{-1}$, cocksfoot cultivar Baraula, $50 \mathrm{~kg} \mathrm{ha}^{-1}$, meadow fescue cultivar $\mathrm{K}-21,50 \mathrm{~kg} \mathrm{ha}^{-1}$ and perennial ryegrass cultivar Esquire also $50 \mathrm{~kg} \mathrm{ha}^{-1}$. Sowing was done in the fall of $2010 \mathrm{on}$ main parcel of area of $10 \mathrm{~m}^{2}$. Table 1.

General agro-chemical properties of soil used in the trial are presented in

Table 1. Main chemical properties of soil

\begin{tabular}{|c|c|c|c|c|c|c|c|c|c|}
\hline \multirow{2}{*}{$\begin{array}{c}\text { Depth } \\
\text { cm }\end{array}$} & $\mathrm{pH}$ & Humus & $\begin{array}{c}\text { Total } \\
\mathrm{N}\end{array}$ & \multirow[t]{2}{*}{$\mathrm{C} / \mathrm{N}$} & \multicolumn{3}{|c|}{$\begin{array}{c}\text { Available N } \\
\mathrm{mg} \mathrm{kg}^{-1}\end{array}$} & \multicolumn{2}{|c|}{ 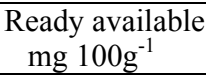 } \\
\hline & $\mathrm{H}_{2} \mathrm{O}$ & \multicolumn{2}{|c|}{$\%$} & & $\mathrm{NH}_{4}-\mathrm{N}$ & $\mathrm{NO}_{3}-\mathrm{N}$ & Ima & $\mathrm{P}_{2} \mathrm{O}_{5}$ & $\mathrm{~K}_{2} \mathrm{O}$ \\
\hline $0-30$ & 6.2 & 0.19 & 3.31 & 10 & 23.1 & 23.8 & 46.9 & 5.4 & 18.4 \\
\hline
\end{tabular}


In the autumn preparation of soil for sowing super phosphate was applied $(18 \%)$. Necessary amount of phosphorus fertilizer was determined based on the content of easy available phosphorus in the soil and requirements of plants that are being grown (Kresović, 2010). Calculated amount of pure nutrient (phosphorus) was $165 \mathrm{~kg} \mathrm{ha}^{-1}$. Fertilization of crops was carried out at the end of March 2011 using mineral fertilizer KAN (27\%).

Based on obtained results for $\mathrm{pH}$ values of the soil, it can be concluded that the soil on which the trial was carried out, belonged to the group of acid soils. According to the humus content, it is medium humus soil (Muckenhausen, 1975), and the total nitrogen content of soil was medium (Bogdanović et al., 2005). C/N ratio was usual for cultivable soils. According to the content of ready available phosphorus, this soil belonged to poor soils, and in regard to the ready available potassium medium soils. Content of ammonium and nitrate nitrogen was balanced and total content of available nitrogen was $46,9 \mathrm{mg} \mathrm{kg}^{-1}$.

\section{Results and Discussion}

Based on obtained results presented in Table 2, in regard to pure crops it can be observed that DM yield showed significant differences. The highest DM yield was recorded for perennial grass in pure crop $\left(5.53 \mathrm{t} \mathrm{ha}^{-1}\right)$, and the lowest in pure alfalfa crop $\left(2.71 \mathrm{t} \mathrm{ha}^{-1}\right)$, which can be explained by agro-climatic conditions which favoured growth of grasses in the period of first cut. Realized yields of mixtures were somewhat higher than yields reported by Lazarević et al. (1999), who recorded the highest yield of mixtures from the first cut of $4.86 \mathrm{t} \mathrm{ha}^{-1}$. Fertilization had significant effect on yield of dry matter in pure crops. It led to increase of yield in all studied cultures. The highest yield was realized by perennial ryegrass in fertilization treatment with $100 \mathrm{kgN} \mathrm{ha}^{-1}$, and the lowest alfalfa in treatments without fertilization. DM yield of mixtures also showed statistically significant differences. The highest yield was recorded in the four component mixture of alfalfa, cocksfoot, meadow fescue and perennial ryegrass $\left(4.49 \mathrm{tha}^{-1}\right)$, and the lowest in mixture of alfalfa and cocksfoot $\left(3.48 \mathrm{t} \mathrm{ha}^{-1}\right)$. In pure crops as well as mixtures, fertilization caused increase of DM yield. The highest yields were recorded in treatments with $100 \mathrm{kgN} \mathrm{ha}^{-1}$, and the lowest in treatments without fertilization. Obtained results are in concordance with results obtained by Nešić (2006), Nešić et al. (2007) and Bijelić (2009) who concluded that treatments with the greatest amount of nitrogen added increased the yield of dry matter of grasslands in the first production year by $18.7 \%$, and in subsequent years from 10.0 to $20.0 \%$. Also, numerous authors report of similar results and conclusions (Hoveland et al., 1995; Malhi et al., 2002, Simić et al. 2006). Proportionally to the sowing level as well as to increase of number of species in mixture, the share of alfalfa and grasses in the yield of dry matter changed significantly. Fertilization with $\mathrm{N}$ also had significant effect on share of all species in mixture. It led to 
decrease of the alfalfa content by $124.80 \mathrm{~g} \mathrm{~kg}^{-1,}$ and increase of cocksfoot by 95.60 $\mathrm{g} \mathrm{kg}^{-1}$ in dry matter of mixtures.

Table 2. Yield of DM in pure crops of alfalfa, cocksfoot, meadow fescue and perennial ryegrass and their mixtures, as well as content of certain species in yield depending on nitrogen fertilization

\begin{tabular}{|c|c|c|c|c|}
\hline \multirow[t]{2}{*}{ Mixture } & \multicolumn{3}{|c|}{ Fertilization $\mathrm{N}\left(\mathrm{kg} \mathrm{ha}^{-1}\right)$} & \multirow{2}{*}{$\begin{array}{l}\text { Mean value } \\
\text { (A) }\end{array}$} \\
\hline & 0 & 50 & 100 & \\
\hline & \multicolumn{3}{|c|}{ Mono culture $\left(\mathrm{t} \mathrm{ha}^{-1}\right)$} & $\left(\mathrm{LSD}_{0.05}=0.242\right)$ \\
\hline Alfalfa & 2.14 & 2.79 & 3.19 & 2.71 \\
\hline Cocksfoot & 3.05 & 3.96 & 4.04 & 3.68 \\
\hline Meadow fescue & 4.52 & 4.68 & 5.20 & 4.80 \\
\hline Perennial ryegrass & 5.38 & 5.22 & 6.01 & 5.53 \\
\hline Mean B $\left(\mathrm{LSD}_{0.05}=0.210\right)$ & 4.16 & 3.77 & 4.61 & \\
\hline & \multicolumn{3}{|c|}{ Mixture $\left(\mathrm{t} \mathrm{ha}^{-1}\right)$} & $\left(\mathrm{LSD}_{0.05}=0.157\right)$ \\
\hline Alfalfa+Cocksfoot & 3.13 & 3.40 & 3.91 & 3.48 \\
\hline Alfalfa+Cocksfoot+Meadow fescue & 3.48 & 4.38 & 4.37 & 4.07 \\
\hline Alfalfa + Cocksfoot + Meadow fescue & 2.62 & 3.94 & 4.61 & 3.72 \\
\hline $\begin{array}{l}\text { Alfalfa }+ \text { Cocksfoot }+ \text { M.fescue }+ \text { Perennial } \\
\text { ryegrass }\end{array}$ & 3.20 & 5.10 & 5.19 & 4.49 \\
\hline Mean A $\left(\operatorname{LSD}_{0.05}=0.136\right)$ & 3.11 & 4.20 & 4.52 & \\
\hline \multicolumn{5}{|c|}{ Alfalfa $\left(\mathrm{g} \mathrm{kg}^{-1}\right)$} \\
\hline Alfalfa+Cocksfoot & 427.70 & 365.00 & 112.00 & 301.60 \\
\hline Alfalfa+Cocksfoot+Meadow fescue & 151.25 & 150.00 & 120.00 & 140.40 \\
\hline Alfalfa + Cocksfoot + Meadow fescue & 88.00 & 80.75 & 50.25 & 73.00 \\
\hline $\begin{array}{l}\text { Alfalfa }+ \text { Cocksfoot }+ \text { M.fescue }+ \text { Perennial } \\
\text { ryegrass }\end{array}$ & 194.50 & 67.50 & 80.00 & 114.00 \\
\hline Mean B $\left(\mathrm{LSD}_{0.05}=12.437\right)$ & 215.40 & 165.80 & 90.60 & \multirow[b]{2}{*}{$\left(\mathrm{LSD}_{0.05}=20.761\right)$} \\
\hline \multicolumn{4}{|c|}{ Cocksfoot $\left(\mathrm{g} \mathrm{kg}^{-1}\right)$} & \\
\hline Alfalfa+Cocksfoot & 575.20 & 630.00 & 888.00 & 696.75 \\
\hline Alfalfa + Cocksfoot + Meadow fescue & 374.00 & 363.50 & 375.75 & 371.10 \\
\hline Alfalfa + Cocksfoot + Meadow fescue & 723.25 & 515.50 & 622.75 & 620.50 \\
\hline $\begin{array}{l}\text { Alfalfa }+ \text { Cocksfoot }+ \text { M.fescue }+ \text { Perennial } \\
\text { ryegrass }\end{array}$ & 46.75 & 227.75 & 212.25 & 167.25 \\
\hline Mean B $\left(\mathrm{LSD}_{0.05}=17.980\right)$ & 429.10 & 437.90 & 524.70 & \\
\hline \multicolumn{5}{|c|}{ Meadow fescue $\left(\mathrm{g} \mathrm{kg}^{-1}\right)$} \\
\hline Alfalfa+Cocksfoot+Meadow fescue & 474.75 & 486.50 & 504.25 & 488.50 \\
\hline Alfalfa + Cocksfoot + Meadow fescue & 188.75 & 403.75 & 327.00 & 306.50 \\
\hline $\begin{array}{l}\text { Alfalfa }+ \text { Cocksfoot }+ \text { M.fescue }+ \text { Perennial } \\
\text { ryegrass }\end{array}$ & 167.50 & 456.75 & 494.00 & 372.75 \\
\hline Mean B $\left(\mathrm{LSD}_{0.05}=20.053\right)$ & 449.00 & 277.00 & 441.75 & \\
\hline \multicolumn{5}{|c|}{ Perennial ryegrass $\left(\mathrm{g} \mathrm{kg}^{-1}\right)$} \\
\hline $\begin{array}{l}\text { Alfalfa }+ \text { cocksfoot }+ \text { M.fescue }+ \text { Perennial } \\
\text { ryegrass }\end{array}$ & 591.25 & 248.00 & 213.75 & \\
\hline Mean B $\left(\mathrm{LSD}_{0.05}=48.620\right)$ & & & & \\
\hline
\end{tabular}

A- factor crop, pure crop and grass-leguminous mixture; B- fertilization $\mathrm{N} ; \mathrm{LSD}_{0.05}-$ Least significant difference at $\mathrm{P} \leq 0.05$ 
The highest content of meadow fescue was recorded in treatment without fertilization - $449.00 \mathrm{~g} \mathrm{~kg}^{-1}$, as well as perennial ryegrass $-591.25 \mathrm{~g} \mathrm{~kg}^{-1}$. Halling and Wallgren (1996) in their study of the effect of $\mathrm{N}$ fertilization, in the amount of $0-200 \mathrm{~kg} \mathrm{ha}^{-1}$, on production characteristics of alfalfa and red clover in mixture with grasses concluded that the share of grasses in mixture increased and share of alfalfa and red clover decreased with the addition of different amounts of nitrogen.

In Table 3 the production of protein in pure crops and grass leguminous mixtures depending on fertilization treatment with different amounts of $\mathrm{N}$ is presented. Alfalfa and cocksfoot realized significantly lower protein yield compared to meadow fescue and perennial ryegrass, as well as mixture of alfalfa and cocksfoot compared to other mixtures.

Perennial ryegrass and grass-leguminous mixture realized the highest protein yield of 495.5 and $568.0 \mathrm{~kg} \mathrm{ha}^{-1}$. This can be explained by the fact that $\mathrm{N}$ fertilization, in addition to the increase of $\mathrm{CP}$ content, also influenced increase of DM yield of perennial ryegrass.

Table 3. Production of proteins in pure crops and their mixtures depending on $\mathbf{N}$ fertilization

\begin{tabular}{|c|c|c|c|c|}
\hline & \multicolumn{3}{|c|}{ Fertilization N $\left(\mathrm{kg} \mathrm{ha}^{-1}\right)$} & Mean value (A) \\
\hline & 0 & 50 & 100 & \\
\hline & \multicolumn{2}{|c|}{ Mono culture $\left(\mathrm{kg} \mathrm{ha}^{-1}\right)$} & \multicolumn{2}{|c|}{$\left(\mathrm{LSD}_{0.05}=27.23\right)$} \\
\hline Alfalfa & 266.2 & 415.3 & 497.1 & 392.9 \\
\hline Cocksfoot & 312.9 & 450.2 & 463.0 & 408.7 \\
\hline Meadow fescue & 336.3 & 406.5 & 600.8 & 447.7 \\
\hline Perennial ryegrass & 417.1 & 521.5 & 547.9 & 495.5 \\
\hline Mean of factor B $\left(\mathrm{LSD}_{0.05}=23.57\right)$ & 333.1 & 448.4 & 527.2 & \\
\hline \multicolumn{4}{|c|}{ Mixture $\left(\mathrm{kg} \mathrm{ha}^{-1}\right)$} & $\left.\mathrm{LSD}_{0.05}=19.40\right)$ \\
\hline Alfalfa + Cocksfoot & 376.2 & 422.9 & 532.9 & 444.0 \\
\hline Alfalfa + Cocksfoot + Meadow fescue & 354.1 & 628.7 & 641.9 & 541.6 \\
\hline Alfalfa + Cocksfoot + Meadow fescue & 238.9 & 468.0 & 599.0 & 435.3 \\
\hline $\begin{array}{l}\text { Alfalfa }+ \text { Cocksfoot }+ \text { Meadow fescue } \\
+ \text { Perennial ryegrass }\end{array}$ & 319.7 & 576.2 & 807.9 & 568.0 \\
\hline Mean of factor B $\left(\mathrm{LSD}_{0.05}=16.80\right)$ & 322.2 & 523.9 & 645.4 & \\
\hline
\end{tabular}

A- factor crop, pure crop and grass-leguminous mixture; B- fertilization N; $\mathrm{LSD}_{0.05}-$ Least significant difference at $\mathrm{P} \leq 0.05$

Fertilization had significant effect on protein yield in mono culture as well as grass-leguminous mixtures Protein yield increased proportionally with the amount of added nitrogen. So, treatment with $100 \mathrm{kgN} \mathrm{ha}^{-1}$ had the highest PY of $527.2 \mathrm{~kg} \mathrm{ha}^{-1}$ in mono culture and $619.0 \mathrm{~kg} \mathrm{ha}^{-1}$ in mixtures. Achieved results are in concordance with results obtained by Nešić (2006) and Bijelić (2009) where it was also established that by adding $\mathrm{n}$ fertilizer in amounts of $0,70,140$ and $210 \mathrm{~kg} \mathrm{ha}^{-1}$ gradual increase of protein yield occurs in pure alfalfa crop and its mixtures with grasses. Stringer et al. (1996) stated that $\mathrm{N}$ fertilization significantly influenced the increase of CP in alfalfa mixture in average by $0,83 \mathrm{~kg} \mathrm{CP} \mathrm{kg}^{-1} \mathrm{~N}$. 


\section{Conclusion}

Based on results of presented research, it can be concluded that alfalfa and grass mono cultures, as well as their mixtures realized significantly different yields of dry matter. The highest DM yield of pure crops was recorded for perennial ryegrass $\left(5.53 \mathrm{t} \mathrm{ha}^{-1}\right)$, and the lowest alfalfa $\left(2.71 \mathrm{t} \mathrm{ha}^{-1}\right)$. Fertilization using different amounts of nitrogen led to significant increase in yield of pure crops and mixtures. The highest yields were determined in treatments with $100 \mathrm{kgN} \mathrm{ha}^{-1}$, and the lowest in treatments without fertilization.

The highest protein yield in pure crops was recorded for perennial ryegrass $\left(495.5 \mathrm{t} \mathrm{ha}^{-1}\right)$, and in mixtures - the four component mixture of alfalfa, cocksfoot, meadow fescue and perennial ryegrass $\left(568.0 \mathrm{~kg} \mathrm{ha}^{-1}\right)$. Nitrogen fertilization significantly influenced the increase of protein yield in pure crops and their mixtures.

Application of $\mathrm{N}$ fertilizers in pure crops of forage plants in the amount from $0-100 \mathrm{~kg} \mathrm{ha}^{-1}$, was completely justifiable since it had positive effect on production of DM and on quality of forage.

This amount of fertilizer is considered economically justifiable, since investment in $100 \mathrm{~kg}$ of nitrogen results in increase of yield of dry matter and protein quality, and quality of forage basis of animal nutrition is improved in this way.

\section{Acknowledgment}

Research was financed by the Ministry of Education and Science, Republic of Serbia, project TR-31053.

\section{Prinos suve materije i produkcija proteina lucerke, ježevice, livadskog vijuka, engleskog ljulja i njihovih smeša sa različitim dozama azotnog đubriva}

\section{Z. Tomić, Z. Bijelić, A. Simić, M. Kresović, M. Žujović, V. Mandić, G.Marinkov}

\section{Rezime}

Travno-leguminozne smeše kao i usevi čistih kultura su od značaja za obezbeđenje kvalitetne kabaste stočne hrane, naročito u uslovima nizijskog stočarstva, u uslovima farmskog držanja kao i pri slobodnom sistemu ispaše 
životinja. Istraživanja su obavljena na čistim usevima tri vrste trava i lucerke, najzastupljenije leguminoze kod nas, kao i njihovih smeša u različitom odnosu učešća pojedinih komponenti. Đubrenje različitim količinama azota dovelo je do značajnog povećanja prinosa kako čistih useva tako i njihovih smeša. Najvećim prinosima odlikuju se tretmani sa $100 \mathrm{kgN} \mathrm{ha}^{-1}$, a najmanjim tretmani bez đubrenja. Đubrenje je smanjilo sadržaj lucerke, livadskog vijuka i engleskog ljulja u suvoj materiji travnjaka, a povećalo sadržaj ježevice. Najvećim prinosom proteina od čistih useva odlikuje se engleski ljulj $\left(495,5 \mathrm{~kg} \mathrm{ha}^{-1}\right)$, a od smeša četvorokomponentna smeša lucerke, ježevice, livadskog vijuka i engleskog ljulja $\left(568,0 \mathrm{~kg} \mathrm{ha}^{-1}\right)$. Đubrenje $\mathrm{N}$ je značajno povećalo prinos proteina kako kod čistih useva tako i kod njihovih smeša.

\section{References}

BIJELIĆ Z. (2009): Uticaj strukture smeše, đubrenja azotom i faze iskorišćavanja na parametre kvaliteta silaža travno-leguminoznih smeša. Poljoprivredni fakultet, Beograd. Doktorska disertacija, 1-146.

BOGDANOVIĆ D., UBAVIĆ M., MALEŠEVIĆ M. (2005): Metode za utvrđivanje potreba biljaka za azotom. In: KASTORI (Ed.): Azot-agrohemijski, agrotehnički, fiziološki i ekološki aspekti. Novi Sad.

ĐORĐEVIĆ N., DINIĆ B. (2003): Siliranje leguminoza. Institut za istraživanja u poljoprivredi, Srbija, Beograd, 226.

ĐORĐEVIĆ N., GRUBIĆ G., RADIVOJEVIĆ M., STOJANOVIĆ B., ADAMOVIĆ O. (2005): Ishrana krava obrocima na bazi različitih vrsta silaža. Zbornik naučnih radova, 11, 3-4, 65-74.

GIL J.L., FICK W.H. (2001): Soil Nitrigen mineralization in mixtures of eastarn gamagrass with alfalfa and red clover. Agronomy Journal, 93, 902-910.

HALLING A.M., WALLGREN B. (1996): Effect of harvest system and nitrogen rate on the performance of lucerne or red clover in mixtures with grass. EGF 96. HOVELAND C.S., DURHAM R.G., BOUTON J.H. (1995): Management effects on productivity of alfagraze alfalfa-tall fescue mixtures. Journal of Production Agriculture, 8, 2, 244-248.

JÖNSSON N. (1982): Blålusern. Resultat av odlingstekninska försök. Swedish University of Agricultural Science, Department of Plant Husbandry, report 99.

KOMAREK P., NERUŠIL P., KOHOUTEK A., ODSTRČILOVA V. (2007): The effect of repeted direct sowing of grass-legume seed mixtures into grasslands on forage production and quality. Grassland Science in Europa, 12, 39-42.

KRESOVIĆ M. (2010): Đubrenje ratarskih i povrtarskih kultura I deo - Metode za određivanje potrebnih količina đubriva. Poljoprivredni fakultet Univerziteta u Beogradu.

LAZAREVIĆ D., STOŠIĆ M., DINIĆ B., TERZIĆ D. (1999): Dynamics of grasslegume mixture production under continuous grazing by sheep. 5 th international 
symposium "New trends in breeding farm animals", Belgrade, 6-8 Oct., Biotechnology in Animal Husbandry, 15, 5-6, 267-272.

LAZARIDOU M., VRAHNAKIS M., NOITSAKIS B. (2006): Performance of legume grass association in the field under drought and cutting conditions. http://www.fao.org/DOCREP/006/AD236E/ad236e0q.htm

MALHI S.S., ZENTNER R.P., HEIER K. (2002): Effectiveness of alfalfa in reducing fertilizer $\mathrm{N}$ input for optimum forage yield, protein concentration, returns and energy performance of bromegrass-alfalfa mixtures. Nutrient Cycling in Agroecosystems, 62, 219-227.

MUCKENHAUSEN E. (1975): Bodenkunde. Frankfurt am Main.

NEŠIĆ Z. (2006): Uticaj đubrenja azotom i udela lucerke na prinos i kvalitet krme sejanog travnjaka. Magistarska teza, Poljoprivredni fakultet, Univerzitet u Beogradu.

NEŠIĆ Z., TOMIĆ Z., VUČKOVIĆ S., RUŽIĆ-MUSLIĆ D. (2007): Prinos travno-leguminoznih smeša u zavisnosti od botanickog sastava i djubrenja azotom. Zbornik radova instituta za ratarstvo i povrtarstvo, 44, 375-379.

OCOKOLJIĆ S., PARIS Z., VELIČKOVIĆ G., STOJANOVIĆ S. (1974): Ispitivanje uticaja kompleksnih mineralnih đubriva na prinos $\mathrm{i}$ kvalitet lucerke $\mathrm{i}$ smeše sa ježevicom. Arhiv za poljoprivredne nauke, 97, 73-82.

OCOKOLJIĆ S., VELIČKOVIĆ G., PARIS Z., NINKOVIĆ S. (1984): Uticaj različitih nivoa đubrenja azotnim i NPK đubrivima na prinos, botanički i hemijski sastav i sadržaj nekih važnijih aminokiselina kod smeše ježevice (Dactylis glomerata) i žutog zvezdana (Lotus corniculatus). Agrohemija, 4, 265-274.

RADOVIĆ J., SOKOLOVIĆ D., MARKOVIĆ J. (2009): Alfalfa-most important perennial forage legume in animal husbandry. Biotechnology in Animal Husbandry, 25, 5-6, 465-476.

SIMIĆ A., ĐORĐEVIĆ N., GRUBIĆ G., VUČKOVIĆ S. (2006): Uticaj prihranjivanja livadske travne smeše na energetsku vrednost dobijenog sena. Biotehnologija u stočarstvu, 22, poseban broj, 489-497.

SPANDL E., HESTERMAN O.B. (1997): Forage quality and alfalfa characteristics in binary mixtures of alfalfa and bromegrass or timothy. Crop Science, 37, 15811585 .

STATSOFT INC. (2001): STATISTICA (data analysis software system), version 6. www.statsoft.com

STRINGER W.C., MORTON B.C., PINKERTON B.W. (1996): Row spacing and nitrogen: Effect on alfalfa - bermudagrass quality components. Agronomy Journal, 88, 573-577.

TEKELI S.A., ATES E. (2005): Yield potential and mineral composition of white clover (Trifolium repens L.) and tall fescue (Festuca arundinaceae Schreb.) mixtures. Journal of Central European Agriculture, 6, 1, 27-34. 